ANUARIO DE Estudios MEdiEvales (AEM)

36/1, enero junio de 2006

pp. 241-252

ISSN 0066-5061

\title{
COMMUNITY, IDENTITY \\ AND THE REDEMPTION OF CAPTIVES: COMPARATIVE PERSPECTIVES ACROSS THE MEDITERRANEAN
}

\author{
JAMES WILLIAM BRODMAN \\ University of Central Arkansas
}

\begin{abstract}
Yvonne Friedman, in Encounters between Enemies (2002), asks why charitable ransoming was more developed and successful in the medieval West than it was in the Latin Kingdom of Jerusalem. This paper seeks to answer this question through an examination of community solidarity. Particularly important to an understanding of western European ransoming customs is the distinction between the deserving poor, who are neighbors, and itinerants and vagabonds who are not. Hispanic ransoming custom, precisely because it emerged within the context of developing municipal communities, was a reflection of this group solidarity; consequently, the caritative ransomers who followed -such as, the Mercedarians and Trinitarians- had to adjust their appeal to conform to these group prejudices. The society of the Latin East, because it was more transient and less cohesive, failed to develop such institutions of solidarity and thus dealt with captives on a more pragmatic, less compassionate basis.

Keywords: Ransoming Orders; Ransoming Alms; 13th century; Mediterranean.
\end{abstract}

\begin{abstract}
Resumen: En su libro Encounters between enemies, Yvonne Friedman se pregunta por qué el rescate caritativo se realizó con mejor resultado en el Occidente medieval que en el reino latino de Jerusalén. Este artículo trata de buscar una respuesta a esta cuestión, examinando la solidariedad comunitaria. Para comprender los sistemas de rescate de Occidente, hay que distinguir entre los pobres vergonzantes, que eran vecinos, y los vagabundos que no merecían esta denominación. El sistema de res cate hispánico que se desarrolló en el contexto de las comunidades municipales que se estaban constituyendo, reflejaba esta solidariedad de grupo. En consecuencia, a partir del siglo XIII, los redentores caritativos (Mercedarios y Trinitarios) tuvieron que adaptarse a esta mentalidad. La sociedad del Este latino no consiguió crear estas instituciones solidarias, por ser más transitoria y menos cohesiva. Por tanto, se ocupó de los cautivos de una forma más pragmática y menos compasiva Palabras clave: Ordenes Redentoras de cautivos; Caridad; Siglo XIII; Mediterráneo
\end{abstract}




\section{CONTENTS}

1. Background. 2. Foral Law 3. The Ransoming Orders 4. Ransoming Alms 5. Begging Licenses

While most studies of medieval ransoming between Christians and Muslims, including my own, have focused on its genesis and practice in Western Europe, the custom itself exists within a wider context. Of the two redemptionist orders that were the focus of my doctoral work at the University of Virginia, one, the Order of the Trinity, disseminated itself widely throughout Europe and the Mediterranean and, to some degree, the spiritual privileges granted by the papacy to Trinitarian benefactors were not limited to those residing in any particular geographical area. As Charles Verlinden pointed out long ago in his general history of medieval slavery, human bondage was a concern throughout the Mediterranean and as a consequence one can see ransoming practiced not only in Spain, but also along the French and Italian coasts as well as in the Crusader East. There has, nonetheless, been a geographical bias to most studies of captivity and ransoming, most likely engendered by the surviving sources which are more copious for the western Mediterranean than for the eastern.

This lacuna in our knowledge has recently been filled by Yvonne Friedman's Encounters between Enemies, which is the first modern study of captivity and ransoming within the Latin Kingdom of Jerusalem during the twelfth and thirteenth centuries. This excellent and comprehensive examination indeed confirms an earlier impression of mine that somehow ransoming institutions were less developed in the East. Friedman demonstrates that the ransoming orders were less active here and that ransoming was even viewed among Latin Christians less favorably as a work of charity than it was by their contemporaries in western Europe. After contrasting Levantine institutions with those of Iberia, Friedman posits that the primary explanation for the West's greater sense of obligation toward the captive and more intensive commitment to ransoming lay in the relative military success of each area of the Crusade. In Spain, the campaigns against Muslims were ultimately successful and this gave occidental societies, she argues, the material resources necessary to redeem captives. The East, plagued with military failure and proportionally larger numbers of captives, simply could not afford the huge cost of ransoms. Spanish society, furthermore, had almost four 
centuries for its customs to crystallize, while Levantine societies had fewer than two ${ }^{1}$.

There is much to Friedman's argument that is undeniable. The Hispanic conflict was more successful for Europeans and the Iberian kingdoms did evolve a legal and institutional tradition that was not equaled in the smaller and more fragmented societies in the East. To use the paradigm suggested by my late mentor, Julian Bishko, Iberia was transformed from a frontier of conquest into one of settlement, while the Crusader States remained western military outposts within the Muslim world, a mere frontier of conquest. The Bishko paradigm is useful because it places legal and institutional traditions within a broader social context and ultimately stresses the significance of community formation as the key to understanding the success of Iberia's territorial expansion and, conversely, the Levantine crusaders' failure. However, it might be argued, ransoming transcends the boundaries of particular communities once it had been elevated - as it was in the twelfth century - to a work of charity. As the needy came to be seen as the "poor of Christ", their relief became a redemptive act for the donor. In theory, this spiritual value of ransoming did not derive from the identity of the captive - he could be friend, or a total stranger, from one's locality or from anywhere else in Christendom. Yet, Friedman's work shows us that this in fact did not happen; occidental captives were privileged over oriental. The question that this paper asks is whether the key difference in ransoming customs stems not from contrasting legal and institutional traditions but from the stronger sense of community that was present in the West, and whether community values limited the actual application of religious ideals.

While the earliest and most basic of ransoming traditions grows out of the family, the great expense of ransoms and the difficulties of arranging ransomings placed such dealings outside the means of all but the most powerful of families. Apart from escape or miracle, the liberation of most captured Christians required the assistance of the broader community. Within Iberia, the earliest signs of this are in the traditions of foral, or municipal, law that emerges first during the twelfth century. The earliest fueros, such as the Aragonese codes of Calatayud (1131) and Daroca (1142) or the Castilian charter of Escalona (1130) merely sought to guarantee the parents of individuals captured from the town a right to purchase a locally-held Muslim

${ }^{1}$ Yvonne FrIEDMAN, Encounters between Enemies: Captivity and Ransoming in the Latin Kingdom of Jerusalem, Leiden, 2002, pp. 250-51. 
slave at a fair price, if the Muslim were then exchanged for the Christian. Charity here was often not an issue since, as in the Cuenca-Teruel fueros, the Christian owner of the Muslim captive was permitted a profit from the sale. Some towns themselves, however, did offer, at a reduced price to families of captives, Muslims who were part of the town's booty and generally exempted such sales from ordinary taxes. The clearest sign of incipient charity within the foral tradition is a limited obligation accepted by towns toward local residents captured while providing military service to the community -reimbursement for a lost horse or equipment and the grant of a Muslim slave, if one were available from the booty, who could be used in any exchange of prisoners ${ }^{2}$.

In addition to regulating the availability and price of Muslim slaves, towns also oversaw those individuals, called exeas or alfaqueques, who actually negotiated ransomings across the military frontier. We know little about such individuals apart from the descriptions in municipal and royal law codes. The usual generalization is that these were merchants who traded in captives, alongside other merchandise peddled between Christians and Muslims. More recently Stephen Bensch has argued that exeas were in fact seasoned warriors like Bernat Marcus, who served in this capacity in midtwelfth-century Catalonia ${ }^{3}$. What is clear, however, is that their work was mercenary and not charitable. The fueros had two concerns regarding these agents: their honesty and the size of their fee (limited in most instances to ten percent of the ransom). Bernat Marcus, himself, bequeathed funds in a will of 1166 for the establishment of a charity hospital at Barcelona. This, however, served pilgrims, abandoned children and the sick poor and provided, so far as we know, no assistance whatsoever to captives ${ }^{4}$.

Foral law leaves an impression of stinginess, leavened only by a willingness to shield captives and their families from being gouged by unscrupulous slave owners and traders, or to assist those captured while actually in service to the town. For the most part, these protections are limited to town residents (vecinos). While normally one would not expect to find

\footnotetext{
${ }^{2}$ For an overview of municipal ransoming, see my Municipal Ransoming Law on the Medieval Spanish Frontier, "Speculum", 60 (1985), pp. 318-30.

${ }^{3}$ Stephen BEnsch, From Prizes of War to Domestic Merchandise: The Changing Face of Slavery in Catalonia and Aragon, "Viator", 25 (1994), pp. 72-73.

${ }^{4}$ For Bernat Marcus' hospital, see my Charity and Welfare: Hospitals and the Poor in Medieval Catalonia, Philadelphia, 1998, p. 33.
} 
many transients or foreigners in these rural communities, one wonders whether the occasional military volunteer or crusader from north of the Pyrenees was also assisted. Families who could not afford to free a loved one must have sought material assistance from their neighbors but it is unclear whether any such aid before the thirteenth century had a charitable connotation. Foral leglislation, in fact, placed strict limits on what individuals could grant out in charity "for their soul" ${ }^{5}$.

The real revolution in charitable ransoming in Western Europe takes place at the end of the twelfth century. Within Iberia, the first glimmerings of ransoming as organized charity are seen in the foundation of several ransoming hospices charged with using endowed income to free captives. Most were operated by the military order of Santiago, although the earliest two, established in 1180 at Toledo and in 1182 at Cuenca, were actually royal foundations. While a few of these institutions would survive into the sixteenth century, they ceased to operate as ransoming institutions within a generation since the military orders which operated them never saw this work as an essential part of their function ${ }^{6}$. The real beginning of charitable ransoming arose out of Pope Innocent III's approval in 1198 of the Order of the Holy Trinity.

The founder of the Trinitarians, St. John de Matha, is a shadowy figure and, as a consequence, we are ignorant of the precise circumstances that gave birth to this new religious order. Its basic roots, however, can be discovered in three places. Giulio Cipollone, the contemporary Trinitarian historian, argues that the pivotal event was the fall of Jerusalem to Saladin in 1187 that commenced a series of calamitous events all along the ChristianMuslim frontier from Palestine to Spain. The enslavement of thousands of Christians and the fear of their apostasy to Islam led Innocent III to patronize John de Matha and to launch a broadly-based effort to raise alms for captives, perhaps paralleling his own efforts to use clerical taxation to support the military aspects of crusading. A second route is suggested by Daniel Le Blévec who argues that Provence, traditionally thought to have been de Matha's home, was particularly important in the late twelfth century as the

${ }^{5}$ For a discussion of such limits, see my What is a soul worth? Pro anima Bequests in the Municipal Legislation of Reconquest Spain, Medievalia et Humanistica, New Series; No. 20, ed. Paul Maurice ClOGAN, New York, 1993, pp. 15-23.

${ }^{6}$ On the hospitals of the military orders, see my Military Redemptionism and the Castilian Reconquest, 1180-1250, Military Affairs 44, (1980), pp. 24-27; Rule and Identity: The Case of the Military Orders, "Catholic Historical Review", 87 (2001), pp. 389-91. 
incubator of new charity movements ${ }^{7}$. Finally, we know from Pope Innocent himself that John was tied to Paris and particularly to the House of St. Victor. While the Rule de Matha would write is eclectic, there are clear borrowings from the Victorines ${ }^{8}$. Is it mere coincidence that Paris was also the seat of intense speculation about the moral rights of the poor and the concomitant duty of all Christians to render assistance, ideas associated with the circle of Peter the Chanter (d. 1197) which itself included several Victorines? ${ }^{9}$ In any case, the appearance of the Trinitarians coincided with this particularly active era of charitable gestation and time of military calamity in the Mediterranean.

While the evidence is fragmentary, both the founder and the pope clearly intended this to be a major initiative on behalf of captives. The Rule, contained in Innocent III's 1198 Bull of confirmation, states that John and his brethren were to liberate at a fair price "captives, who are imprisoned by the pagans on account of their faith in Christ" and pagan captives "so that afterwards a Christian may be freed through a reasonable trade and good faith for a pagan according to the rank and status of their persons". This would soon be depicted iconographically in a mosaic of 1210 at the Order's house in Rome that depicts Christ in majesty, bracketed by two captives, one Christian and one Muslim, surrounded by the legend of its name: The Order of the Holy Trinity and of Captives. This work of caritative ransoming was financed by the Order's statutory commitment of one-third of all its revenues for this work ${ }^{10}$. The pope, for his part, attempted to intercede with Muslim rulers so that they would permit the friars entry into their realms for purposes of ransoming. While any correspondence with eastern rulers has been lost, a letter of March 8, 1199 to the Almohad sultan who ruled Morocco and

${ }^{7}$ Giulio CIPOLlone, Cristianità-Islam. Cattività e liberazione in nome di Dio -Il tiempo di Innocenzo III dopo 'il 1187', Rome, 1992, pp. 325-50. LE BLEVEC notes that, between 1170 and 1190 , this region saw the appearance of Guy of Montpellier and his hospitaller Order, the arrival of the Antonines in Marseilles, and the commencement of St. Bénézet's Bridge Builders at Avignon. See his Le contexte parisien et provençal de la règle des Trinitaires, in Liberazione dei "captivi" tra Cristianità e Islam. Otre la crociata e il gihad: tolleranza e servizio umanitario, ed. Giulio CiPOLlone, Vatican City, 2000, pp. 124-26.

${ }^{8}$ James M. Powell, Innocent III, the Trinitarians, and the Renewal of the Church, 11981200, in La liberazione dei "captivi", p. 250.

${ }^{9}$ John W. BALDWIN, Masters, Princes and Merchants: The Social Views of Peter the Chanter and His Circle, vol. 1, Princeton, 1970, pp. 18-21, 236-37.

${ }^{10} \mathrm{PL}, 214: 445$, no. 3 On the mosaic, see Giulio Cipollone, Il mosaico di S. Tommaso in Formis a Roma (ca. 1210). Contributo di iconografia e iconologia, Rome, 1984, pp. 86-105. 
southern Spain, Amir al-Mu'minin survives as a testimony to this papal initiative $^{11}$.

Statistically, the Trinitarians became a successful order. At the end of the Middle Ages, they held some 154 houses in twelve provinces: six in France, two in the British Isles (12 houses in England and Scotland), and four in Iberia ${ }^{12}$. Yet Pope Innocent's dream of a broadly-based caritative initiative on behalf of Christian captives was never realized; indeed it quickly fell victim to localized self-interest and to the Order's own conflicted sense of mission. From the beginning, de Matha also directed his followers to serve other needy Christians within Europe itself; as a consequence, the primitive Rule of 1198 reserved a second third of the Order's income for the more traditional works of hospitality ${ }^{13}$. As a consequence, Trinitarians founded or accepted the care of hospitals located throughout Europe. But in northern France, and elsewhere, resistence eventually developed to the use of local resources for ransoms, especially after the debacle of Louis IX's crusade to Egypt in 1248. In 1261, even the house in Rome, St. Thomas in Formis, was exempted by Pope Urban IV from contributing toward ransoms ${ }^{14}$. Furthermore, the Rule itself was revised during the thirteenth-century to weaken the obligation of individual Trinitarian houses to pay the ransoming third and, by the early fifteenth century, the Order formally replaced it with a fixed tax or quota assessed against each house ${ }^{15}$. There was less resistance, 1346.

${ }^{11}$ Cipollone, Christianità-Islam, 506, no. 26; PL, 214: 544-45.

${ }^{12}$ G. Cipollone, Trinitari, Dizionario degli istituti di perfezione, vol. 9, Rome, 1974-, p.

${ }^{13}$ Section 12 of the Rule suggests that the Order's apostolate to the poor would be limited: "the care of guests and of the poor and of all those coming and going is to be given to one of the more able and kinder brothers who will listen to them and then, as he sees fit, administer the solace of charity. Nevertheless, he should demand from those whom he believes should be admitted if they will be content with whatever the brothers give them. For it is not fitting that anyone be let in for rich and fancy food. ... If anyone, especially religious, arrive seeking hospitality, let them be received kindly and charitably according to the means of the house." The Trinitarians, however, were not to provide feed for their animals unless it could not be purchased locally. PL, 214, 446, no. 12.

${ }^{14} \mathrm{Grants}$ to the Trinitarians in the places like Compiègne, Meaux and Vianden contain such a restriction. James William BRODMAN, The Trinitarian and Mercedarian Orders: A Study of Religious Redemptionism in the Thirteenth Century, Unpublished Ph.D. dissertation, University of Virginia, 1974, p. 237. CIPOLlONE, Trinitari, p. 1345.

${ }^{15}$ In the revision of 1263 , an additional provision allows that the ransoming third should be deducted when the will of the donor cannot clearly be discerned; it also permits a Trinitarian to act as the donor's agent in withholding the ransoming third. The quota system was established by the Chapter General at Cerfroid in 1429. See Sergio PAGANO, Il testo della Regoli dei Trinitari (1198): redazione, annotazioni diplomatiche, aggiornamenti del secolo XIII, in Liberazione dei 
however, to ransoming in arenas where captivity remained an issue, namely in the Iberian peninsula. Here in 1304 King Ferdinand IV of Castile, in his endowment of the Order's house at Burgos, listed the ransoming of captives first in his list of its obligations; and the Order's revised constitutions of 1429 speak of ransomings as the work of its Iberian provinces and within them as the efforts of individual houses or, at most, of small groupings of them ${ }^{16}$.

The Order of Mercy, the second of Europe's caritative ransoming orders, was more focused upon the liberation of captives than were the Trinitarians. But, as a consequence, during the medieval era, it never developed a presence far from the coastlines of the Mediterranean. Furthermore, unlike the Trinitarian Order, it had no direct connection to the Palestinian crusades ${ }^{17}$. Pere Nolasc, its founder, is as little known as John de Matha; he may have been from Barcelona or from Languedoc in France. His new order emerges out of the Catalan assault upon Majorca in 1229 and its initial growth is tied to King Jaume I's additional conquest of Valencia and Castile's occupation of Andalusia and Murcia. In 1317 there were some two hundred brothers divided among 57 houses in mainland Spain, the Balearics and southern France. The Order's geography remained relatively static until the end of the Middle Ages. In 1474 there were 550 Mercedarians in just 62 houses $^{18}$.

Apart from serving the spiritual and even material needs of its benefactors, the Mercedarians -- and Iberian Trinitarians did much the same things -- devoted their energies to collecting alms on behalf of captives which were then parceled out as subsidies to individual families or used to finance direct ransoming missions conducted by the Order to Muslim towns in Granada or North Africa, where the brothers would purchase the liberty of

"captivi", p. 83, $\mathrm{n}^{\circ}$. 4; Josep HeRnANDO, La "tercia pars" en la regla de los Trinitarios para el rescate de cautivos: una forma de inversión económica, de economía evangélica, in Liberazione dei "captivi", p. 269.

${ }^{16}$ Documentación del monasterio de La Trinidad de Burgos (1198-1400), ed. Lucía GARCíA ARAGón, Burgos, 1985, pp. 81-84, no. 45 (April 6, 1304); Statuta ordinis pro Hispaniae provinciis a capitulo generali anno 1429 Cervifrigidi habito approbata, Acta Ordinis Sanctissimae Trinitatis, 2 (1925), p. 128

${ }^{17}$ The principal modern studies of the Mercedarians are my Ransoming Captives in Crusader Spain: The Order of Merced on the Christian-Islamic Frontier, Philadelphia, 1986; and Bruce TAYLOR, Structures of Reform: The Mercedarian Order in the Spanish Golden Age, Leiden, 2000.

${ }^{18}$ For a survey of the medieval development of the Mercedarians, see my Ransoming Captives, pp. 15-40; a brief summary is contained in James W. BRODMAN, The Mercedarians, Encyclopedia of Monasticism, vol. 2, Chicago, 2000, pp. 855-56. 
captive Christians. Alms themselves would come from patrimonial endowments, testimentary gifts, collection boxes placed at urban locales like neighborhood ovens, and direct appeals. Such gifts were encouraged by an array of indulgences granted by the papacy and by parades of returned captives who gave personal testimony of their sufferings at the hands of the Moors. The evidence for these ransomings is very fragmented and estimates of those so helped are highly speculative. Nonetheless, in Iberia at least something akin to Innocent III's dream of a system of assistance to Christians too poor to ransom themselves was successfully established; furthermore it functioned beyond the end of the Middle Ages to the dawn of modernity ${ }^{19}$.

There are clear signs, however, that this system of charity functioned more narrowly than Pope Innocent had intended and in fact served a clientele closely bound by geography, ethnicity and kinship to those who in fact provided the material support. Contextually, in fact, caritative ransoming displays the same divide that begins to appear everywhere in Europe between the poor in general and the so-called deserving or shame-faced poor ${ }^{20}$. For captives, this meant that the Mercedarians and Trinitarians generally provided direct and indirect assistance only to individuals from particular regions. Some of this derived from the political influence exerted upon the ransoming orders, especially on the Mercedarians, in the fourteenth and fifteenth centuries that saw Aragonese monarchs appropriating ransoming alms to finance military actions against Muslim rulers as well as against coastal pirates and demanding large sums to support the ransoming of particular royal favorites ${ }^{21}$. There was, of course, some benefit to the Mercedarians from this royal peculation, namely the king's efforts to protect the Order from rival charities, such as

${ }^{19}$ Enrique Gozalbes CRAVIOTO, La liberación de cautivos en los últimos años del reino nazarí de Granada, in La liberazione dei "captivi", p. 750. TAYLOR, Structures of Reform, p. 57; BRODMAN, Ransoming Captives, pp. 113-15.

${ }^{20}$ For a discussion of this distinction, its development and importance, see my Charity and Welfare, pp. 4-7, 141-42.

${ }^{21}$ See my Ransomers as Royal Agents: The Mercedarians and the Aragonese Crown in the Fourteenth Century, in Iberia and the Mediterranean World of the Middle Ages, Vol. 2: Proceedings from Spain and the Mediterranean World, ed. P.E. CHEVEDDEN, D.J. KAGAY and P.G. PADILlA, Leiden, 1996), p. 248; Maria Teresa FERRER, La redempció de captius a la corona catalano-aragonesa (segle XIV), "Anuario de Estudios Medievales", 15 (1985), pp. 254, 271-74. For examples of the royal appropriation of revenue from other charitable institutions, see my Charity and Welfare, pp. 16, 65. 
local confraternities or the Trinitarians, and from the resistence of local officials to Mercedarians collecting alms within their towns ${ }^{22}$.

Some of this tendency to assist local causes, however, stemmed from the preferences of society itself. The evidence, for lack of any modern study of the Trinitarians in Spain, is overwhelmingly Mercedarian but I doubt that the experience of one order would contradict that of the other. First of all, the few and scattered instances of Mercedarian ransomings reveal a local bias. For example, the Mercedarians at Vic, a town in Catalonia, doled out subsidies in the later thirteenth century to some sixty-two residents of the town. The earliest known captive lists, dating from 1366 and 1388, show Mercedarians from Catalonia and Valencia traveling to North Africa to purchase the freedom of fifty captives, all natives of territory controlled by the king of Aragon. The document of 1388 notes that these individuals were selected from the very large number of Christians held captive there. ${ }^{23}$ The existence of a parochial expectation for charity is revealed in the complaints from councilors of the Valencian town of Morella in 1384 that the Mercedarians were refusing to ransom certain local residents despite the funds that the town had already contributed to the Order, or in the will of Elionor Sacirera, a wealthy Barcelona widow who in 1441 demanded that her alms be withheld from both the Mercedarians and Trinitarians and instead be given to local merchants who could be trusted to deliver captives ${ }^{24}$. Secondly, the Merced Order itself divided along regional lines in the mid-fifteenth century into Castilian and Aragonese provinces which became virtually autonomous. While the reasons for this are complicated, one of the consequences was the organization at the end of the Middle Ages of separate ransoming expeditions by brothers of the two regions, one directed toward the liberation of Castilians and the other at those from the crown lands of Aragon ${ }^{25}$. Consequently, it becomes clear that medieval ransomers were closely tied to their communities.

\footnotetext{
${ }^{22}$ For an overview of such royal protection, see Regina SÁINZ DE LA MAZA, Los mercedarios en la Corona de Aragón durante la segunda mitad del siglo XIV. Noticias y Documentos, "Miscel-lània de Textos Medievals", 4 (1988), pp. 228-32.

${ }^{23}$ Brodman, Ransoming Captives, pp. 105-7, 114.

${ }^{24}$ SÁINZ DE LA MAZA, Los mercedarios, pp. 240, 286-87, no. 31 (April 4, 1384); Julià Nuria COLL, Documentación notarial relativa a los pobres en la Cataluña del siglo XV, in La pobreza y la asistencia a los pobres en la Cataluña medieval, ed. Manuel RIU, vol. 2, Barcelona, 1981-82, p. 307. p. 750

${ }^{25}$ TAYLOR, Structures of Reform, 57-63; GOZALBES CRAVIOTO, La liberación de cautivos,
} 
Alms were given to them in the expectation that local residents would be freed and the evidence that survives shows that this is precisely what the friars did.

The local character of ransoming is even more apparent in the exercise of private charity in the later Middle Ages. This existed in several forms, some of which have been studied recently by Jarbel Rodriguez ${ }^{26}$. One very common practice is found in testimentary grants that designate small sums for the ransom of captives. These could be dispensed at the discretion of the decedent's manumissors, the local parish priest or, as becomes very common, the ransoming orders. Rodriguez, for example, cites a letter of 1441 written on behalf of Valencia's city council to the executors of a recently deceased woman from Terol asking that the $£ 10$ provided by her testament be used toward the ransom of a local resident being held captive in Algiers. Indeed, Valencia seems to have been very proactive in assisting families in raising these ransoms. In 1323 the council established a municipal system that pooled alms from poor boxes, wills and collections into a fund that would subsidize the ransoms of captured and needy local Christian residents up to the amount of $£ 15$. On a smaller scale, numerous craft and professional confraternities all along the Mediterranean coast promised ransoming subsidies for members or their dependents who had been captured ${ }^{27}$.

The most frequent type of assistance to captives provided by the Aragonese crown and by bishops as well was permission for a captive's family to beg publically for ransom monies. These licenses were valid in specific locales for limited durations of time, although there are instances of these being extended for upwards of five years or more because of the rapid escalation during the fourteenth century of the price commanded by captives. The license, which presumably would have to be displayed publically to legitimize the activity, contained the name of the captive, the place of his captivity, and a description his suffering while in Muslim hands. Consequently, this represents a direct personal appeal from one individual and his family to the consciences of individual town residents. Because cities like Barcelona in the fourteenth century limited entry of foreign beggars to no

\footnotetext{
${ }^{26}$ See his Financing a Captive's Ransom in Late Medieval Aragon, "Medieval Encounters", 9 (2003), pp. 164-81.

${ }^{27}$ See RoDRÍGUEZ, Financing a Captive's Ransom, pp.175, 179-80. 
more than one day, one assumes that possessors of such licenses concentrated their efforts on areas in which they were known and welcomed ${ }^{28}$.

Medieval redemptionism in Spain and elsewhere became at the end of the Middle Ages a complex tangle of institutions, both secular and religious, and of piety, personal tragedy, and law. While one assumes that large numbers of those who were the victims of war and piracy never achieved their liberation, a fortunate minority was restored to their homes and families. Around 1200 Pope Innocent III seems to have envisioned a broad effort to free the victims of the Christian-Islamic conflict coordinated by an international agency - the Trinitarians - who would collect alms from tens of thousands of the faithful and then dispense them to benefit those thousands held in captivity. Perforce, this charity would have to be anonymous in character and motivated by religious ideas, be it the salvation of the donor or the preservation of the captive in his Christian faith. In short, this would be the typical "Catholic" form of charity that modern polemicists have contrasted with more selfish "Protestant" charity. But, as I have argued elsewhere, medieval charity was rarely this altruistic. The liberation of captives is only another illustration of that point ${ }^{29}$. Consequently, captives who lacked the support of a family or of a community were least likely to achieve freedom through ransoming. Perhaps, it is this reality more than any other that explains the failure of this form of charity in the Crusader East.

\footnotetext{
${ }^{28}$ Rodríguez argues that it would take the family of an unskilled worker upwards of twentyfive years, and between two and five years for that of a master craftsman, to pay the price of a ransom out of its own resources See his Financing a Captive's Ransom, pp.170-73. On restrictions on begging in Barcelona, see my Charity and Welfare, p. 141.

${ }^{29}$ For a discussion of "Catholic" vs. "Protestant" ideas of charity and its application to the Middle Ages, see my Charity and Welfare, pp. 4-7, 136-43, 203, n. 31. 